\title{
ANTIDIABETIC ACTIVITY OF ENDOPHYTIC FUNGI ISOLATED FROM FICUS RELIGIOSA
}

\author{
PALAK TIWARI, NATHIYA R, GAYATHRI MAHALINGAM*
}

Department of Biotechnology, School of Biosciences \& Technology, VIT University, Vellore - 632 014, Tamil Nadu, India. Email: gayathrigopinath@vit.ac.in

Received: 15 August 2016, Revised and Accepted: 20 January 2017

ABSTRACT

Objective: The aim was to study in vitro antidiabetic activity of endophytic fungi isolated from Ficus religiosa.

Methods: The explants (leaves and stem) were processed on the potato dextrose media nine colonies were found and colony frequency was calculated. All the colonies were transferred onto potato dextrose broth and incubated for 21 days. The crude was extracted using three solvents petroleum ether (0.1), diethyl ether (2.8), and ethyl acetate (4.4). Three assays were performed to determine in vitro antidiabetic activity of crude extract ( $\alpha$-amylase inhibition assay, $\alpha$-glucosidase inhibition assay, and glucose diffusion assay) and the percentage of inhibition by crude and standard acarbose was calculated with standard error mean.

Results: The endophytic fungi show the highest percentage of inhibition for $\alpha$-amylase inhibition assay (91\% \pm 0.06 ), $\alpha$-glucosidase inhibition assay $(42 \% \pm 0.01)$.

Conclusion: The results indicate that the hypoglycemic activity of the endophytic crude extract has been proved, hence further studies are focused onto isolate and purify the bioactive compounds and test for in vivo animal studies to confirm the antidiabetic activity.

Keywords: Endophytic fungi, Antidiabetic activity, $\alpha$-amylase, $\alpha$-glucosidase.

(C) 2017 The Authors. Published by Innovare Academic Sciences Pvt Ltd. This is an open access article under the CC BY license (http://creativecommons. org/licenses/by/4. 0/) DOI: http://dx.doi.org/10.22159/ajpcr.2017.v10i4.14718

\section{INTRODUCTION}

Endophytes are mutualistic symbiont harbors inside the living tissues of healthy plants without causing any symptoms and it can be fungi, bacteria, and actinomycetes [1]. Due to long host-parasitic relationship endophytes can produce the secondary metabolites same that of plants. They are rich source of secondary metabolites such as antibacteria [1], antifungus [2], antidiabetic [3], and anticancer activity [4]. From practical point of view, drug production by endophytic microbes fermentation will give more profit since it will be fast, reproducible, unlimited and weather/season independent. Easy to increase microbial capability by genetic engineering and different cultivation condition, we can produce different products. The discovery of endophytic fungi with capability to produce the exactly same active compound produced by their host leads to a new approach in active compound production from natural product commercially $[8,9]$. Production of useful compounds can be increased by endophytic fungi biotechnology for affording demands while keeping biodiversity and ecosystem sustainable [5]. Endophytes have attracted attention in the search for novel bioactive natural compounds that can be used as new drugs replacing those against which pathogenic strains have rapidly acquired resistance [15]. Ficus religiosa pharmaceutically important plant belonging to the family Moraceae commonly called as fig family it is used against various diseases such as diabetes, asthma, diarrhea, epilepsy, and gastric problems [1,14]. Diabetes mellitus is a metabolic disorder which occurs due to impaired glucose regulation or impaired regulation of enzyme $\alpha$-amylase. It is associated with an increased risk of cardiovascular disease.

The stability of alpha amylase was better [10] the crystallization of isozymes in alpha amylase was also done [11]

Most cases of diabetes involve many genes with each being a small contributor to an increased probability of becoming Type 2 diabetic and it also depends on the life style. Diabetes mellitus is of two types: Type 1 and Type 2 .
Type 2 diabetes accounts for about $90-95 \%$ of all diagnosed cases of diabetes.

Drug which generally used for Type 2 diabetes is acarbose, actos oral, metformin, and Welchol oral.

\section{METHODS}

\section{Sampling}

The stem and leaf of plant $F$. religiosa obtained from Vellore, Tamil Nadu was used for investigation and isolation.

\section{Isolation of endophytic fungi}

Isolation of endophytic fungus was standardized and modified based on the method described by Hallman et al., (2007). The samples were washed with running tap water and $70 \%$ ethanol for 1 minute. Surface sterilization to remove adhering microorganism was done by immersion in $4 \%$ sodium hypochlorite for 3 minutes. Then rinsed with ethanol and finally with distilled water. Blot dried on sterile tissue paper. The stems were cut into explants $1 \mathrm{~mm} \times 1 \mathrm{~mm}$ in size in aseptic condition using a sterile scalpel. Samples were cultured in Petri dishes containing potato dextrose agar medium. The Petri dishes sealed with Parafilm and incubated at $27^{\circ} \mathrm{C}$ and monitored every day.

All the seven colonies subcultured in potato dextrose broth for 21 days. After 21 days each sample was extracted with three solvents petroleum ether, diethyl ether, and ethyl acetate. Broth was filtered using Whatman No 1 filter paper, broth and mycelium mat was obtained. Mycelium mat and broth was first extracted based on polarity from petroleum ether followed by diethyl ether and ethyl acetate. Equal volume of petroleum ether and broth were mix vigorously in the separating funnel and allow it to settle down for 2 hrs then broth was collected in the beaker and solvent with crude were taken in a Petri plate.

Solvent was evaporated in some time then crude was collected. 
Antidiabetic assay such as $\alpha$-amylase, $\alpha$-glucosidase, and glucose diffusion test were performed for the obtained crude extract.

\section{$\alpha$-amylase inhibition assay}

About $1 \mathrm{mg}$ of each crude dissolved in $50 \%$ of dimethyl sulfoxide. $100 \mathrm{ml}$ of $0.1 \mathrm{M}$ phosphate buffer was prepared. $1 \mathrm{mg}$ of enzyme $\alpha$-amylase slowly dissolved in $1 \mathrm{ml}$ phosphate buffer. $100 \mu \mathrm{l}$ of solution (enzyme + buffer) added in each test tube. $100 \mu \mathrm{l}$ of different concentration of test samples was added $(100 \mu \mathrm{g}, 200 \mu \mathrm{g}, 300 \mu \mathrm{g}$ and $400 \mu \mathrm{g})$ in each test tube. Incubate it for 10 minutes at $25^{\circ} \mathrm{C}$.

After that $100 \mu \mathrm{l}$ of $1 \%$ starch solution was added incubate it for 10 minutes at $37^{\circ} \mathrm{C}$ then $200 \mu \mathrm{l}$ of 3,5 dinitrosalycylic acid (DNSA) solution was added and incubated in boiling water for 10 minutes. Cool it to room temperature then $200 \mu \mathrm{l}$ of $40 \%$ Rochelle salt was added then all the samples were diluted with $2 \mathrm{ml}$ distilled water. Absorbance was taken at $540 \mathrm{~nm}$ [3].

\section{$\alpha$-glucosidase inhibition assay}

About $1 \mathrm{U} / \mathrm{ml}$ of enzyme dissolved in $100 \mu \mathrm{l}$ of $0.1 \mathrm{~m}$ phosphate buffer (pH 6.9). $50 \mu \mathrm{l}$ of crude of different concentration of crude extract taken in the 96 well microtiter plates incubate it for 10 minutes at $25^{\circ} \mathrm{C} .50 \mu \mathrm{l}$ of $50 \mathrm{mM}$ p-nitrophenyl $\alpha$-D glucopyranosidase (prepared in phosphate buffer) and incubate it for 15 minutes at $37^{\circ} \mathrm{C}$. Add $50 \mu$ l of stop reagent $1 \mathrm{M}$ sodium carbonate. Absorbance at $405 \mathrm{~nm}$ [3].

\section{Glucose diffusion test}

Four different concentrations (200, $150 \mu \mathrm{g} / \mathrm{ml}, 100 \mu \mathrm{g} / \mathrm{ml}$, and $50 \mu \mathrm{g} / \mathrm{ml}$ ) of crude extract were prepared. $1 \mathrm{ml}$ of extract was placed in a dialysis membrane $(12,000 \mathrm{MV}$, Hi Media Laboratories Mumbai, India) and $1 \mathrm{ml}$ of $0.22 \mathrm{mM}$ glucose in $0.15 \mathrm{M} \mathrm{NaCl}$ was added. Then the dialysis membrane was tied at both ends and immersed in a beaker containing $40 \mathrm{ml} 0.15 \mathrm{M} \mathrm{NaCl}$ and $10 \mathrm{ml}$ of distilled water. For control $1 \mathrm{ml}$ of $0.22 \mathrm{mM}$ glucose in $0.15 \mathrm{M} \mathrm{NaCl}$ was added in dialysis membrane bag along with $1 \mathrm{ml}$ of distilled water and immersed in a beaker $(40 \mathrm{ml}$ $0.15 \mathrm{M} \mathrm{NaCl}+10 \mathrm{ml}$ distilled water). The beakers were kept at room temperature. The glucose movement from internal solution to external solution (beaker solution) was measured every $1 / 2 \mathrm{hr}$ by DNSA method. Three replications were done for every $1 / 2 \mathrm{hr}$ for $3 \mathrm{hrs}$ [6].

\section{RESULTS}

A total of 21 endophytic fungi were isolated from the stem and leaf explants of F.religiosa. Among which 9 pure endophytic colonies were isolated and subjected to further study. Leaves given highest yield of endophytic fungi than compare to stem explants. The isolation and colonization rate was given in the table 1 .

The fermented broth of 5 pure cultures was further subjected to $\mathrm{v} / \mathrm{v}$ (1:1) solvent extraction and the yield was calculated. When compare to all the crude extracts petroleum ether (PE) given highest yield shown in table 2.

Fig. 1 shows the percentage of inhibition by acarbose and crude samples in $\alpha$-amylase assay. Each bar represents percentage of inhibition by acarbose (blue) and crude sample (red) with \pm standard error of mean (SEM).

Fig. 2 shows the percentage of inhibition by acarbose and crude in $\alpha$ glucosidase assay. Each bar represents \% of inhibition by acarbose (blue) and crude sample (red) in $\alpha$ glucosidase assay with \pm SEM.

Fig. 3 shows the microscopic observation of fungus 1 in lacto phenol cotton blue staining technique. The fungi was further subjected to sequencing to know the genus and species of the fungus 1.

\section{DISCUSSION}

Medicines for diabetes from the plants are presently under limited use. The inhibition by natural products is safer than synthetic drug. The synthetic drugs cause more side effects than the natural products [6]. F. religiosa is a traditional medicinal plant known for its antifungal

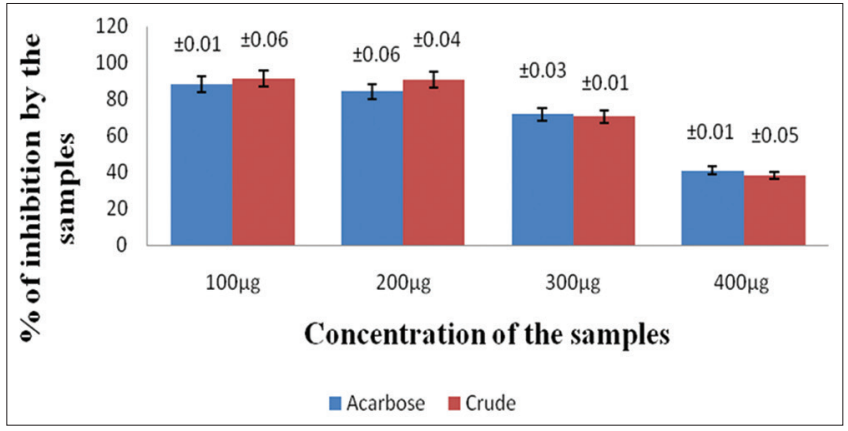

Fig. 1: $\alpha$-amylase inhibition assay

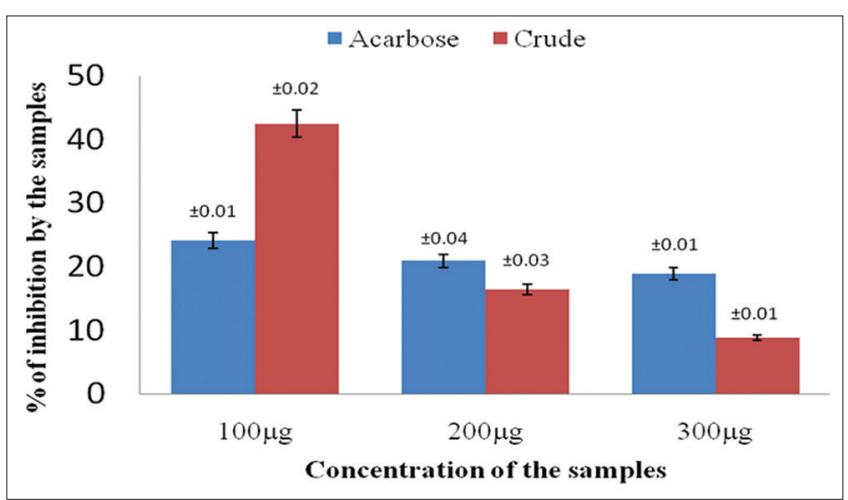

Fig. 2: $\alpha$-glucosidase inhibition assay

Table 1: Isolation and colonization and rate of endophytic fungi of $F$ religiosa

\begin{tabular}{llll}
\hline Ficus religiosa & Stem & Leaf & Total \\
\hline Number of explants from F. religiosa & 10 & 20 & 30 \\
Number of explants yielding fungi & 6 & 15 & 21 \\
Number of isolates & 3 & 6 & 9 \\
Isolation rate (\%) & 30 & 30 & 30 \\
Colonization rate (\%) & 60 & 75 & 70 \\
\hline
\end{tabular}

F. religiosa: Ficus religiosa

Table 2: Yield of fungi (1-7) with three solvents

\begin{tabular}{llll}
\hline Fungi & Petroleum ether & Diethyl ether & Ethyl acetate \\
\hline Fungi 1 & $20 \pm 0.012$ & $2 \pm 0.045$ & $2 \pm 0.012$ \\
Fungi 2 & $16 \pm 0.016$ & $1 \pm 0.023$ & $1 \pm 0.016$ \\
Fungi 3 & $9 \pm 0.012$ & $1 \pm 0.036$ & $1 \pm 0.02$ \\
Fungi 4 & $10 \pm 0.021$ & $1 \pm 0.012$ & $1 \pm 0.017$ \\
Fungi 5 & $4 \pm 0.015$ & $2 \pm 0.017$ & $1 \pm 0.015$ \\
\hline
\end{tabular}

Data represented with \pm standard deviation

Table 3: $\alpha$-amylase study results percentage of inhibition by crude extract with standard error mean using three different solvent

\begin{tabular}{lllll}
\hline Solvents & $\mathbf{1 0 0} \mathbf{\mu g}$ & $\mathbf{2 0 0} \boldsymbol{\mu g}$ & $\mathbf{3 0 0} \boldsymbol{\mu g}$ & $\mathbf{4 0 0} \boldsymbol{\mu g}$ \\
\hline $\begin{array}{l}\text { Petroleum } \\
\text { ether }\end{array}$ & $91.32 \pm 0.05$ & $90.70 \pm 0.01$ & $71.27 \pm 0.04$ & $39.12 \pm 0.06$ \\
$\begin{array}{l}\text { Diethyl } \\
\text { ether }\end{array}$ & $47.69 \pm 0.01$ & $41.46 \pm 0.03$ & $46.66 \pm 0.04$ & $41.46 \pm 0.01$ \\
$\begin{array}{l}\text { Ethyl } \\
\text { acetate }\end{array}$ & $85.36 \pm 0.01$ & $75.06 \pm 0.04$ & $63.95 \pm 0.07$ & $57.18 \pm 0.04$ \\
\hline
\end{tabular}

Data represented with \pm standard deviation

antidiabetic, antiasthmatic, and anticancer activity [13]. In this study, endophytic fungi isolated from stems of $F$. religiosa is explored for its 
Table 4: Glucose concentration after every hour in glucose diffusion assay

\begin{tabular}{|c|c|c|c|}
\hline $\begin{array}{l}\text { Concentration of } \\
\text { crude sample }\end{array}$ & $\begin{array}{l}\text { Glucose concentration }(\mathrm{mg}) \text { after } 1 \mathrm{hr} \\
\text { Control - }(2.42 \pm 0.01)\end{array}$ & $\begin{array}{l}\text { Glucose concentration (mg) } 2 \text { hrs } \\
\text { Control - }(3.25 \pm 0.03)\end{array}$ & $\begin{array}{l}\text { Glucose concentration (mg) } 3 \text { hrs } \\
\text { Control - }(3.57 \pm 0.01)\end{array}$ \\
\hline $100 \mu \mathrm{g}$ & $1.8 \pm 0.04$ & $2.2 \pm 0.04$ & $2.2 \pm 0.01$ \\
\hline $200 \mu \mathrm{g}$ & $1.5 \pm 0.02$ & $1.71 \pm 0.08$ & $2.1 \pm 0.03$ \\
\hline $300 \mu \mathrm{g}$ & $1.5 \pm 0.09$ & $1.8 \pm 0.02$ & $1.9 \pm 0.04$ \\
\hline $400 \mu \mathrm{g}$ & $1.8 \pm 0.02$ & $1.76 \pm 0.06$ & $1.6 \pm 0.02$ \\
\hline
\end{tabular}

Values are mean \pm SEM for group of three observations. SEM: Standard error of mean

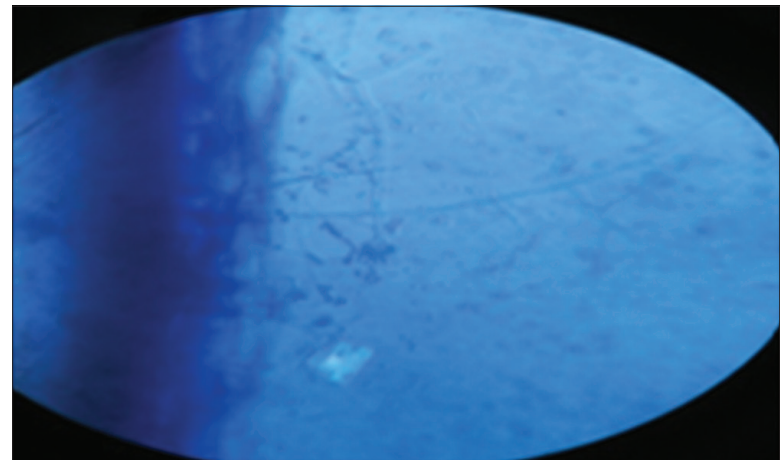

Fig. 3: Microscopic image of crude endophytic fungi

$\alpha$-glucosidase and $\alpha$-amylase inhibitory potential with its mechanism of action similar to that of standard acarbose [12]. Black colored colonies were observed and the highest colony frequency found to be $60 \%$. Assays such as $\alpha$-amalyse inhibition assay, $\alpha$-glucosidase inhibition assay, and glucose diffusion test show positive and camparable results for the crude extract when campared with standard acarbose. Microscopic view of endophytic fungi indicates that it might be Aspergillus species.

The results for $\alpha$-amylase inhibition assay are given in Table 3. It was observed that petroleum ether (polarity index-0.1) extract had the highest inhibitory action on the activity of $\alpha$-amylase. The activity of standard acarbose and crude extract was compared in Fig. 1. It was observed that at the lower concentration crude extract showed maximum inhibition activity with $(91 \% \pm 0.06)$ percentage [6]

The activity of standard acarbose and crude extract in the $\alpha$-glucosidase inhibition study was compared in Fig. 2. It was observed that at lower concentration crude extract showed maximum inhibition activity with $(42 \% \pm 0.01)$ percentage [6]

The results of glucose diffusion study are given in Table 4 here the petroleum extract showed maximum inhibition to the movement of glucose outside the membrane. It managed to prevent efflux of glucose. It could make effective agent for controlling diabetes [6,7].

\section{CONCLUSION}

This study concludes that the fungi 1 which is Aspergillus species shows the highest percentage of inhibition for $\alpha$-amylase inhibition assay $(91 \% \pm 0.06)$, $\alpha$-glucosidase inhibition assay $(42 \% \pm 0.01)$ and showed good results in glucose diffusion assay. The results indicate that the hypoglycemic activity of the endophytic crude extract has been proved, hence further studies are focused onto isolate and purify the bioactive compounds and test for in vivo animal studies to confirm the antidiabetic activity.

Hence, endophytic fungi isolated from F religiosa can be used for treatment of Type 2 diabetes.

\section{ACKNOWLEDGMENTS}

Authors would like to thank the management of VIT University for supporting this study.

\section{REFERENCES}

1. Rajagopal K, Sundharamoorthy M, Arumugam P, Basha WJ, Govindarajan K, Rajendran R. In vitro anti bacterial activity of endophytic fungal extracts isolated from a pharmaceutically important plant Ficus religiosa L. Int J Pharm Bio Sci 2015;6(4):1093-8.

2. Azevedo JL, Maccheroni JW, Pereira JO. Endophytic microorganisms: A review on insect control and recent advances on tropical plants. Electron J Biotechnol 2000;3(1):40-65.

3. Subashini D, Subhashree V. Antioxidant and $\alpha$-amylase inhibition activities of phenolic compounds in the extracts of Indian honey. Chin J Nat Med 2012;10(4):255-9.

4. Lakshmi PJ, Selvi KV. Anticancer potentials of secondary metabolites from endophytes of Barringtonia acutangula and its molecular characterization. Int J Curr Microbiol Appl Sci 2013;2(2):44-5.

5. Onifade AK. Research trends: Bioactive metabolites of fungal origin. Res J Biol Sci 2007;2:81-4.

6. Picot C, Subratty AH, Mahomoodally MF. Inhibitory potential of five traditionally used native antidiabetic medicinal plants on $\alpha$-amylase, $\alpha$-glucosidase, glucose entrapment, and amylolysis kinetics in vitro. Adv Pharmacol Sci 2014;2014:1-7.

7. Bouché C, Serdy S, Kahn CR, Goldfine AB. The cellular fate of glucose and its relevance in Type 2 diabetes. Endocr Rev 2004;25(5):807-30.

8. Strobel G, Daisy B, Castillo U. The biological promise of microbial endophytes and their natural products. Plant Pathol J 2005;4(2):161-76.

9. Grover JK, Yadav S, Vats V. Medicinal plants of India with anti-diabetic potential. J Ethnopharmacol 2002;81(1):81-100

10. Janecek S, Baláz S. Alpha-amylases and approaches leading to their enhanced stability. FEBS Lett 1992;304(1):1-3.

11. Muus J, Vnenchak JM. Isozymes of salivary amylase. Nature 1964;204:283-5.

12. Prabhavathy D, Nachiyar V. Antimicrobial and antidiabetic activity of an endophytic fungi isolated from Adathoda beddomei. Int J Pharm Pharm Sci 2013;5(3):780-3.

13. Chandrasekar SB, Bhanumathy M, Pawar AT, Somasundaram T. Phytopharmacology of Ficus religiosa. Pharmacogn Rev 2010;4(8):195-9.

14. Singh D, Singh B, Goel RK. Traditional uses, phytochemistry and pharmacology of Ficus religiosa: A review. J Ethnopharmacol 2011;134(3):565-83.

15. Tan RX, Zou WX. Endophytes: A rich source of functional metabolites. Nat Prod Rep 2001;18(4):448-59. 